\title{
COMPARISON OF KNOWLEDGE, ATTITUDES AND BEHAVIOUR OF HEALTH PROFESSIONALS AND PARENTS REGARDING CHILD INJURIES
}

\author{
Nikolina Brčina ${ }^{1}$, Aida Mujkić ${ }^{2}$, Milan Milošević ${ }^{2}$, Maja Miškulin ${ }^{3}$, Anne Baber Wallis ${ }^{4}$ \\ ${ }^{1}$ Health Centre Zagreb, Zagreb, Croatia \\ ${ }^{2}$ School of Medicine, Andrija Stampar School of Public Health, University of Zagreb, Zagreb, Croatia \\ ${ }^{3}$ School of Medicine, University of Osijek, Osijek, Croatia \\ ${ }^{4}$ University of Wisconsin-Madison, Madison, USA
}

\begin{abstract}
SUMMARY
Objective: We wanted to primarily examine the knowledge, attitudes and behaviour of parents and health workers (community nurses and paediatricians) regarding child injuries in order to understand the essence of the problem and to find out the most common misconceptions.

Methods: Respondents were tested through an anonymous, self-administered questionnaire and all p values below 0.05 were considered significant.

Results: Of all respondents, paediatricians answered accurately most of the questions considering knowledge than the other groups. More than $90 \%$ of respondents, in all groups, identified correct answers to 10 questions about attitudes towards child injury prevention and safety promotion.

Conclusion: This study, which shows the current level of knowledge, attitudes and behaviour patterns of parents and health professionals in Croatia, could help in the preparation of appropriate prevention programmes.
\end{abstract}

Key words: child injury prevention, knowledge, behaviour, attitude, health professionals, parents

Address for correspondence: N. Brčina, Health Centre Zagreb, Švarcova 20, Zagreb, Croatia. E-mail: nikolinabrcina@gmail.com

\section{INTRODUCTION}

Unintentional injuries are the leading cause of death and hospitalization in children worldwide $(1,2)$, and are becoming not just a national but also a public health problem. According to the World Health Organization (WHO), injuries and violence are major "killers" of children, responsible each year for about 950,000 deaths of children and young people under the age of 18. Unintentional injuries account for almost $90 \%$ of these cases. Tens of millions of children are hospitalized because of non-fatal injuries, and many of them suffer from lifelong disabilities (3). Most injuries occur at home under parental supervision (4). Some studies have shown that many parents believe that unintentional injuries are a normal part of childhood and they do not see themselves as being capable of preventing those types of injuries (5).

Parents who thought that they have little control over injuries had children with more non-minor injuries, and protective parents who worried more about their child's safety had children with a history of fewer non-minor injuries (6). Many parents agreed that most of the injuries could be avoided (7) and some parents believed that childhood injuries are of developmental function, because according to them, injuries serve the purpose of "teaching children a lesson" to avoid those type of situations which provoked the injuries in the future (5). Very small numbers of studies have explored the knowledge of health professionals and their role in injury prevention (8). Transferring knowledge to and counselling parents by health professionals was considered in some studies
(9-13). Most health professionals have a positive attitude towards counselling parents, but a lack of time and materials are mentioned as a main reason for little preventive practice $(9,10,13)$. Some health workers pointed out that they do not believe they could effectively prevent and reduce child unintentional injuries $(11,12)$. Some of them mentioned several reasons for not talking to parents during routine consultation, such as reasons for consultations that do not permit such an approach: "the fact that injuries are not priorities for them"; "the unsuitability of the place where the contact occurs for such discussion, given the time required"; "insufficient information on the subject"; and "the patient's lack of interest" (10). Others expressed some barriers to counselling such as "inadequate time during clinic visits"; "inadequate time to follow up with the parent if a risk is identified"; "didn't think to ask"; and "there are more important things to do" (13). Given that WHO states that each country should investigate the problem of child injuries in their country and prepare appropriate preventive programmes (14), we therefore wanted to primarily examine the knowledge, attitudes and behaviour patterns of parents and health workers in order to understand the essence of the problem and to find out the most common misconceptions. Only by having those results can we properly develop child injury prevention programmes.

As child safety deserves high priority, the goal of the present study was to compare the knowledge, attitudes and behaviour of medical professionals, namely primary paediatricians and community nurses, and parents regarding child injury prevention and safety promotion. 


\section{MATERIALS AND METHODS}

The participants included 236 paediatricians $(100 \%$ of those practicing at the primary level of healthcare) and 409 community nurses ( $51 \%$ of those from the whole territory of Croatia) as the representatives of the health care professionals. Addresses for licensed physicians were obtained from the Registry of Health Workers (15). Between May and July 2007, an anonymous, selfadministered questionnaire was mailed to the offices of a stratified, random sample of licensed practitioners selected to represent the territory of the Republic of Croatia. The mail included a cover letter that described the study and a pre-addressed, pre-stamped return envelope. Return of the questionnaire was considered consent to participate. The response rates for paediatricians and community nurses were $37 \%$ and $46 \%$, respectively, what is also considered the main limitation of this study.

The survey was subdivided into three sets of questions that addressed safety knowledge, attitudes, and behaviour.

First-time mothers filled out the questionnaire during their stay in the maternity ward at the Clinical Hospital Centre Zagreb in Zagreb. The questionnaires for fathers were given to the mothers to take home and fathers returned the completed questionnaires (in a pre-addressed, pre-stamped return envelope) by post. The sample included 285 mothers and 66 fathers with response rates of $77 \%$ and $23 \%$, respectively

The collected data are shown in the Tables. Differences in answers regarding knowledge, attitudes and behaviour between parents, community nurses and paediatricians were assessed with the chi square test and were shown in frequencies and percentages. All $p$ values below 0.05 were considered significant. Statistical package IBM SPSS Statistics, version 19.0.0.1 (www.spss.com) has been used in all statistical procedures.

\section{RESULTS}

In this study, 99 paediatricians, 188 community nurses and 299 parents completed the questionnaire.

\section{Knowledge Regarding Child Injury Prevention and Safety Promotion}

Table 1 shows paticipants' knowledge regarding child injury prevention and safety promotion. More than $80 \%$ of health professionals gave the correct answer regarding injuries as the leading cause of child mortality after the 1 st year of life in Croatia, while only $65 \%$ of parents identified injuries as the leading cause. More than $90 \%$ of all participants answered correctly the question about not leaving newborns on elevated surfaces - the question with the highest number of correct responses.

The question with the lowest number of correct responses was about the safest infant sleeping position, to which just $17 \%$ of paediatricians, $13 \%$ of parents and $1 \%$ of community nurses responded correctly.

Table 1. Health professionals' and parents'knowledge regarding causation, prevention and safety promotion of childhood injuries

\begin{tabular}{|c|c|c|c|c|c|}
\hline Questions & Correct answers & $\begin{array}{l}\text { Community nurse } \\
\quad \mathrm{N}=188 \\
\mathrm{n} \text { correct }(\%)\end{array}$ & $\begin{array}{l}\text { Paediatrician } \\
\qquad \mathrm{N}=99 \\
\mathrm{n} \text { correct }(\%)\end{array}$ & $\begin{array}{c}\text { Parent } \\
\mathrm{N}=299 \\
\mathrm{n} \text { correct }(\%)\end{array}$ & $p$ value \\
\hline $\begin{array}{l}\text { Leading cause of child mortality after } \\
1 \text { st year of life in Croatia }\end{array}$ & Injuries & $153(81.4)$ & $87(87.9)$ & $196(65.6)$ & $<0.001$ \\
\hline $\begin{array}{l}\text { The leading causes of fatal accidents } \\
\text { among children aged } 1-4 \text { years in } \\
\text { Croatia }\end{array}$ & Traffic accidents & $116(61.7)$ & $70(70.7)$ & $171(57.2)$ & $<0.001$ \\
\hline $\begin{array}{l}\text { The most common cause of poison- } \\
\text { ing among children in Croatia }\end{array}$ & Household chemicals & $153(81.4)$ & $75(75.8)$ & $192(64.2)$ & $<0.001$ \\
\hline The safest infant sleep position & On the back & $2(1.1)$ & $17(17.2)$ & $41(13.7)$ & 0.002 \\
\hline Baby walker with wheels & $\begin{array}{l}\text { Is dangerous because of possibility of } \\
\text { falls }\end{array}$ & $165(87.8)$ & $92(92.9)$ & $90(30.1)$ & $<0.001$ \\
\hline $\begin{array}{l}\text { While shopping in the shopping } \\
\text { centre the parent of a child under } \\
\text { age of } 5\end{array}$ & $\begin{array}{l}\text { Should hold him/her by his/her hand all } \\
\text { the time }\end{array}$ & $171(91.0)$ & $93(93.9)$ & $256(85.6)$ & 0.013 \\
\hline $\begin{array}{l}\text { Proper storage of household chemi- } \\
\text { cals in households with children } \\
\text { under age of } 5\end{array}$ & $\begin{array}{l}\text { Chemicals should be stored in child- } \\
\text { proof bottles in locked cupboard }\end{array}$ & $163(86.7)$ & $91(91.9)$ & $214(71.6)$ & $<0.001$ \\
\hline $\begin{array}{l}\text { Mother is changing a newborn baby's } \\
\text { diaper on an elevated surface. In the } \\
\text { case of telephone ringing she should }\end{array}$ & $\begin{array}{l}\text { Cover the baby with the blanket, take } \\
\text { the baby into her arms and go to the } \\
\text { phone }\end{array}$ & $183(97.3)$ & $97(98.0)$ & $281(94.0)$ & 0.296 \\
\hline \multirow{4}{*}{ Child can poison himself/herself with } & Dietary supplements that contain iron & $1(0.5)$ & $8(8.1)$ & $1(0.3)$ & \multirow{4}{*}{$<0.001$} \\
\hline & Medications in childproof bottles & $1(0.5)$ & $0(0.0)$ & $5(1.7)$ & \\
\hline & $\begin{array}{l}\text { Silica gel (globules in shoe boxes or } \\
\text { medications that absorb moisture) }\end{array}$ & $14(7.4)$ & $8(8.1)$ & $103(34.4)$ & \\
\hline & All mentioned things $(a+b+c)$ & $157(83.5)$ & $71(71.7)$ & $169(56.5)$ & \\
\hline
\end{tabular}

Chi square test was used, and $p$ values below 0.05 were considered significant. 
Of all respondents, paediatricians answered accurately most of the questions compared to other groups, exept on questions regarding poisoning among children in Croatia, which received the most correct answers from community nurses.

\section{Attitudes towards Child Injury Prevention and Safety Promotion}

Attitudes among participants were examined in 21 questions. More than $90 \%$ of respondents, in all groups, identified correct answers to 10 questions. These question are shown in Table 2 and refer to child safety indoors (bathtub safety) and outdoors (traffic safety, playground safety), parent and child education, and factors such as alcohol and firearms. Participants had less safety-prone attitudes on other questions as shown in Table 2. The bigges difference in attitude between health professionals and parents was shown by the question regarding issues of confidentiality about child abuse, which stated that health care workers should keep a professional secret if a child confessed to him/her that he/ she has been abused (which is not the recommended attitude); $73.9 \%$ of community nurses and $82.8 \%$ of paediatricians disagreed with this question, but just $7.7 \%$ of parents disagreed. The proper attitude that it is not recommended to provoke vomiting after ingesting a potentially poisonous substance was answered correctly by $63.6 \%$ of paediatricians, $35.6 \%$ of community nurses and $18.7 \%$ of parents.

\section{Behaviour towards Child Injury Prevention and Safety Promotion}

Nine questions were used to find out whether health professionals and parents behave adequately when it comes to safety of children (Table 3 ).

Some participants showed improper behaviour considering the installation of a CO detector in households and less than $20 \%$ of parents demonstrated adequate behaviour about storing chemicals outside of the original packaging. Appropriate behaviour in the lowering of boiler water temperature was noticed more among parents $(48.2 \%)$ than among health professionals (community nurses $35.5 \%$; paediatricians $25.3 \%$ ). Among health professionals, the main differences in proper acting involved the questions about recommending protective covers for electric sockets and baby gates on stairways, locking the gates and warning parents of the danger of falls from heights, on which community nurses provided the highest level of proper behaviour responses.

\section{DISCUSSION}

The role of health professionals, especially those at the primary healthcare level, in childhood injury prevention could be very important. We will discuss mainly primary level prevention as well as other levels of prevention. In "real life" situations it seems that the potential for intervention is not always used in the best way. Health professionals' knowledge of childhood injuries is limited in some areas and we confirmed that in our research where we found incorrect answers given by health professionals to some specific questions. For some questions, for example putting protective covers on electric sockets, the lowering of a boiler water temperature, and the installation of a carbon monoxide detector in households at higher risk (gas boilers and stoves, braziers, connection to city gas line), the parents gave a higher percentage of correct answers than the health professionals. In some other questions, parents gave the correct answer more often than community nurses, e.g. regarding the safest infant sleep position on the back, and to another question about locking the front gate or yard gate, parents answered more correctly than paediatricians. That is a sign that the parents got the information from other sources, most likely from the media or non-governmental organizations. To some questions high proportion of health professionals gave the correct answers but the same questions were correctly answered by very low percentage of parents. This shows that the transfer of knowledge to the parents is not always successful.

In the study of Gielen et al., more than three quarters of parents knew that injuries are the leading cause of death for children, showing a level of knowledge similar to our participating parents. In the same study, almost all parents (96\%) reported having a working smoke detector, but according to the answers of our parents' sample only $22.7 \%$ would install a carbon monoxide detector in households at higher risk (gas boilers and stoves, braziers, connection to city gas line). $48.2 \%$ parents from our study reported that they would lower the boiler water temperature, and in the Gielen et. al study only $3 \%$ of each study group reported knowing the temperature of their hot water. Among our participants, health professionals showed sufficent knowledge regarding the danger of baby walkers with wheels, which was known to $88 \%$ of community nurses and $93 \%$ of paediatricians. However, parents from our study showed a low level of knowledge, as only 30\% knew about the possible dangers of baby walkers, which was similar to the results of the Gielen study in which more than $65 \%$ of parents were planning to use a baby walker (16). Parents who protected the stairs by using baby gates were mentioned in some studies, e.g. Evans and Kohli (17) and Gielen et al. (16) noted that $48 \%$ and $80 \%$ of parents, respectively, used that sort of protection. $70.6 \%$ of parents from our study use gates as protection for stairs.

In the Cohen and Runyan study almost all paediatric health professionals (94\%) knew that injury was the leading cause of death for children aged 1 to 4 (13), showing similar results to our study in which $81.4 \%$ of comunnity nurses and $87.9 \%$ of paediatricians gave the proper answer. Cohen and Runyan also found that knowledge of injury and poisoning epidemiology, tap water temperature and use of baby walkers was limited, with the average correctly answered at only $62 \%(8,13)$. Our health professionals showed better knowledge regarding these questions with the lowest level of correct answers at 76\%, except the question about lowering boiler water temeperature. $68 \%$ of paediatric health professionals from the Cohen and Runyan study considered it important to ask parents about safety hazards at home (13).

Most of the studies dealt with knowledge of health professionals and recommended to further improve it, especially through training programmes and noted that health professionlas would like to be involved in injury prevention progammes but mentioned a lack of time as a major issue (8).

Even though deaths by poisioninig are rare, a large number of children suffer non-fatal injuries as a result of poisoning (18). Since this was considered to be an important matter, through several questions (e.g., "What is the most common cause of poisoning among children in Croatia?"; "What is the proper 
Table 2. Health professionals and parents correct attitudes (\%) towards child injury prevention and safety promotion

\begin{tabular}{|c|c|c|c|c|c|}
\hline Questions & Correct attitude & $\begin{array}{c}\text { Community nurse } \\
\mathrm{N}=188 \\
\mathrm{n} \text { correct }(\%)\end{array}$ & $\begin{array}{l}\text { Paediatrician } \\
\quad \mathrm{N}=99 \\
\text { n correct }(\%)\end{array}$ & $\begin{array}{c}\text { Parent } \\
\mathrm{N}=299 \\
\mathrm{n} \text { correct }(\%)\end{array}$ & $\mathrm{p}$ value \\
\hline $\begin{array}{l}\text { Baby that can sit down can be left alone unsupervised } \\
\text { for a few minutes in the bathtub containing } 10 \text { centim- } \\
\text { eters of water and plastic toys to play with }\end{array}$ & Disagree & $182(96.8)$ & $99(100.0)$ & $294(98.3)$ & 0.975 \\
\hline $\begin{array}{l}\text { Pre-school child can sit in the front seat of a car if } \\
\text { mother or some other adult person holds him/her in herl } \\
\text { his lap }\end{array}$ & Disagree & $181(96.3)$ & $99(100.0)$ & $293(98.0)$ & 0.591 \\
\hline $\begin{array}{l}\text { When he/she learns the meaning of a paedestrian } \\
\text { crossing and traffic light signals, a } 5 \text { year old child can } \\
\text { cross a street alone }\end{array}$ & Disagree & $180(95.7)$ & $97(98.0)$ & $275(92.0)$ & 0.002 \\
\hline $\begin{array}{l}\text { On the children's playground nothing dangerous can } \\
\text { happen to a child }\end{array}$ & Disagree & $183(97.3)$ & $98(99.0)$ & $290(97.0)$ & 0.113 \\
\hline $\begin{array}{l}\text { Small child can stand between the front seats of a car } \\
\text { while the car is being driven if he/she holds himself/ } \\
\text { herself with hands }\end{array}$ & Disagree & $182(96.8)$ & $99(100.0)$ & $292(97.7)$ & 0.587 \\
\hline $\begin{array}{l}\text { It is enough to educate only one parent about child } \\
\text { safety }\end{array}$ & Disagree & $182(96.8)$ & $95(96.0)$ & $281(94.0)$ & 0.051 \\
\hline $\begin{array}{l}\text { If a pre-school child misbehaves during a guest's visit } \\
\text { he/she should be locked in another room until the } \\
\text { guests have gone away }\end{array}$ & Disagree & $184(97.9)$ & $95(96.0)$ & $284(95.0)$ & 0.467 \\
\hline Some children can be educated only with spanking & Disagree & $181(96.3)$ & $95(96.0)$ & $275(92.0)$ & 0.047 \\
\hline $\begin{array}{l}\text { Small amounts of alcohol will not harm a pre-school } \\
\text { child }\end{array}$ & Disagree & $186(98.9)$ & $96(97.0)$ & $286(95.7)$ & 0.148 \\
\hline $\begin{array}{l}\text { Firearms in the home do not represent a threat to a } \\
\text { pre-school child because he or she does not know how } \\
\text { to use it and he or she cannot handle it }\end{array}$ & Disagree & $185(98.4)$ & $96(97.0)$ & $285(95.3)$ & 0.178 \\
\hline $\begin{array}{l}\text { It is good idea for a mother to lie down on a sofa and } \\
\text { have a short nap with her baby after breastfeeding } \\
\text { during the day }\end{array}$ & Disagree & $153(81.4)$ & $87(87.9)$ & $170(56,9)$ & $<0.001$ \\
\hline $\begin{array}{l}\text { One should teach pre-school children to not touch } \\
\text { medications, and after that they will not touch them }\end{array}$ & Disagree & $152(80.9)$ & $81(81.8)$ & $158(52.8)$ & $<0.001$ \\
\hline $\begin{array}{l}\text { If the child swallows some potentially poisonous sub- } \\
\text { stance it is important to instantly provoke vomiting }\end{array}$ & Disagree & $67(35.6)$ & $63(63.6)$ & $56(18.7)$ & $<0.001$ \\
\hline Parent must always be rigorous and authoritative & Disagree & $132(70.2)$ & $67(67.7)$ & $153(51.2)$ & $<0.001$ \\
\hline Missing regular vaccinations is a form of child neglect & Agree & $169(89.9)$ & $93(93.9)$ & $261(87.3)$ & 0.133 \\
\hline $\begin{array}{l}\text { The older children in the family should watch after the } \\
\text { younger ones }\end{array}$ & Disagree & $158(84.0)$ & $76(76.8)$ & $159(53.2)$ & $<0.001$ \\
\hline $\begin{array}{l}\text { Parent is allowed to slap a child if he/she has no other } \\
\text { choice }\end{array}$ & Disagree & $151(80.3)$ & $73(73.7)$ & $229(76.6)$ & 0.252 \\
\hline $\begin{array}{l}\text { Governess/teacher (in kindergarten, school) is allowed } \\
\text { to spank a child in order to discipline him or her }\end{array}$ & Disagree & $180(95.7)$ & $89(89.9)$ & $262(87.6)$ & 0.061 \\
\hline If an infant does not stop crying, shaking it will help & Disagree & $181(96.3)$ & $95(96.0)$ & $255(85.3)$ & $<0.001$ \\
\hline $\begin{array}{l}\text { One should not stop children's fighting in a kinder- } \\
\text { garten because it is the way to prepare them for life }\end{array}$ & Disagree & $176(93.6)$ & $89(89.9)$ & $266(89.0)$ & 0.191 \\
\hline $\begin{array}{l}\text { Health care workers should keep a professional secret } \\
\text { if a child confesses to him or her that he or she has } \\
\text { been abused }\end{array}$ & Disagree & $139(73.9)$ & $82(82.8)$ & $23(7.7)$ & $<0.001$ \\
\hline
\end{tabular}

Chi square test was used, and all p values below 0.05 were considered significant.

way to store household chemicals in households with children under age of 5?"; "What if the child swallows some potentially poisonous substance: is it important to instantly try to provoke vomiting?"; and question about keeping chemicals outside of their original packages with proper labels etc.), we wanted to highlight the importance of the proper handling of toxic chemicals within reach of children. The most incorrect responses by all respondents concerned the question related to the provocation of vomiting, which was answered correctly by just $19 \%$ of parents, $36 \%$ of community nurses and $64 \%$ of paediatricians. 
Table 3. Health professionals and parents answers to questions regarding behaviour towards child injury prevention and safety promotion

\begin{tabular}{|c|c|c|c|c|c|}
\hline \multicolumn{2}{|l|}{ Questions } & $\begin{array}{l}\text { Community nurse } \\
\qquad \begin{array}{c}N=188 \\
n(\%)\end{array}\end{array}$ & $\begin{array}{l}\text { Paediatrician } \\
\qquad \begin{array}{l}\mathrm{N}=99 \\
\mathrm{n}(\%)\end{array}\end{array}$ & $\begin{array}{c}\text { Parent } \\
\mathrm{N}=299 \\
\mathrm{n}(\%)\end{array}$ & $\mathrm{p}$ value \\
\hline \multirow[t]{3}{*}{ I am aware of the danger of falls from heights } & Yes & $152(80.9)$ & $67(67.7)$ & $216(72.2)$ & \multirow{3}{*}{0.070} \\
\hline & No & $35(18.6)$ & $28(28.3)$ & $79(26.4)$ & \\
\hline & Missing & $1(0.5)$ & $4(4.0)$ & $4(1.3)$ & \\
\hline \multirow{3}{*}{$\begin{array}{l}\text { I think it is beneficial to put protective covers on electric } \\
\text { sockets }\end{array}$} & Yes & $162(86.2)$ & $58(58.6)$ & $280(93.6)$ & \multirow{3}{*}{$<0.001$} \\
\hline & No & $25(13.3)$ & $39(39.4)$ & $14(4.7)$ & \\
\hline & Missing & $1(0.5)$ & $2(2.0)$ & $5(1.7)$ & \\
\hline \multirow[t]{3}{*}{ I think it is beneficial to use baby gates on a stairway } & Yes & $172(91.5)$ & $61(61.6)$ & $211(70.6)$ & \multirow{3}{*}{$<0.001$} \\
\hline & No & $16(8.5)$ & $36(36.4)$ & $55(18.4)$ & \\
\hline & Missing & $0(0.0)$ & $2(2.0)$ & $33(11.0)$ & \\
\hline \multirow[t]{3}{*}{ To lower the temperature of the hot water heater } & Yes & $63(33.5)$ & $25(25.3)$ & $144(48.2)$ & \multirow{3}{*}{$<0.001$} \\
\hline & No & $124(66.0)$ & $72(72.7)$ & $138(46.2)$ & \\
\hline & Missing & $1(0.5)$ & $2(2.0)$ & $17(5.7)$ & \\
\hline \multirow[t]{3}{*}{ I am aware of the danger of small objects } & Yes & $167(88.8)$ & $79(79.8)$ & $201(67.2)$ & \multirow{3}{*}{$<0.001$} \\
\hline & No & $21(11.2)$ & $18(18.2)$ & $94(31.4)$ & \\
\hline & Missing & $0(0.0)$ & $2(2.0)$ & $4(1.3)$ & \\
\hline \multirow[t]{3}{*}{ I think it is beneficial to lock the front gate or yard gate } & Yes & $151(80.3)$ & $55(55.6)$ & $236(78.9)$ & \multirow{3}{*}{$<0.001$} \\
\hline & No & $37(19.7)$ & $42(42.4)$ & $57(19.1)$ & \\
\hline & Missing & $0(0.0)$ & $2(2.0)$ & $6(2.0)$ & \\
\hline \multirow{3}{*}{$\begin{array}{l}\text { I have identified where the household chemicals and } \\
\text { medications have been stored }\end{array}$} & Yes & $85(45.2)$ & $33(33.3)$ & $217(72.6)$ & \multirow{3}{*}{$<0.001$} \\
\hline & No & $101(53.7)$ & $60(60.6)$ & 74 (24.7) & \\
\hline & Missing & $2(1.1)$ & $6(6.1)$ & $8(2.7)$ & \\
\hline \multirow{3}{*}{$\begin{array}{l}\text { I think it is beneficial to install a carbon monoxide detec- } \\
\text { tor in households at higher risk (gas boilers and stoves, } \\
\text { braziers, connection to city gas line) }\end{array}$} & Yes & $28(14.9)$ & 21 (21.2) & $68(22.7)$ & \multirow{3}{*}{0.168} \\
\hline & No & $157(83.5)$ & 74 (74.7) & $221(73.9)$ & \\
\hline & Missing & $3(1.6)$ & $4(4.0)$ & $10(3.3)$ & \\
\hline \multirow{3}{*}{$\begin{array}{l}\text { I am aware of the danger of keeping chemicals outside } \\
\text { of their original packages and without proper labels (for } \\
\text { example, to not keep chemicals for cleaning in a juice } \\
\text { bottle or in the original packages without proper labels) }\end{array}$} & Yes & $135(71.8)$ & $67(67.7)$ & $50(16.7)$ & \multirow{3}{*}{$<0.001$} \\
\hline & No & $53(28.2)$ & $29(29.3)$ & $240(80.3)$ & \\
\hline & Missing & $0(0.0)$ & $3(3.0)$ & $9(3.0)$ & \\
\hline
\end{tabular}

Chi square test was used, and all p values below 0.05 were considered significant.

Keeping household cleaners, medicines and vitamins out of reach of children, was pointed out as the best preventive measure by parents in the study of Vincenten et al. (7). But, it is also very important to point out that only $6 \%$ of parents in that study mentioned that the most important preventive measure was the installation of smoke detectors (7). We believe that there is a place for improvement in knowledge among all our participants about prevention with carbon monoxide detectors, especially among health professionals because only $15 \%$ of community nurses and $21 \%$ of paediatricians would recommend the installation of a carbon monoxide detector. The education of healthcare providers should definitely be improved in this area so they could translate knowledge about this issue into everyday practice.

\section{CONCLUSION}

WHO states that each country should investigate the problem of childhood injuries in order to prepare appropriate prevention programmes (14). This study, which shows the current level of knowledge, attitudes and behaviour of parents and health professionals in Croatia by uncovering common areas of misconception and a lack of awareness regarding childhood injury prevention, could help in the effort towards achieving this goal.

\section{Acknowledgements}

The survey was developed as a part of the project titled "Injury Prevention and Safety Promotion for Pre-School Children", funded by the Croatian Ministry of Science, Education and Sport. This project also received partial support from the University of Iowa Injury Prevention Research Center (CDC CCR 703640) and the University of Iowa International Trauma Training Program (NIHFIC 2D43 TW007261).

\section{Conflict of Interests}

None declared 


\section{REFERENCES}

1. Valent F, Little D, Bertollini R, Nemer LE, Barbone F, Tamburlini G. Burden of disease attributable to selected environmental factors and injury among children and adolescents in Europe. Lancet. 2004 Jun 19;363(9426):2032-9.

2. Canadian Institute of Child Health. The health of Canada's children: a CICH profile. 3rd ed. Ottawa: Canadian Institute of Child Health; 2000.

3. World Health Organization. The global burden of disease: 2004 update. Geneva: WHO; 2008.

4. Shanon A, Bashaw B, Lewis J, Feldman W. Nonfatal childhood injuries: a survey at the Children's Hospital of eastern Ontario. CMAJ. 1992 Feb $1 ; 146(3): 361-5$.

5. Morrongiello BA, Dayler L. A community-based study of parents' knowledge, attitudes and beliefs related to childhood injuries. Can J Public Health. 1996 Nov-Dec;87(6):383-8.

6. Morrongiello BA, House K. Measuring parent attributes and supervision behaviors relevant to child injury risk: examining the usefulness of questionnaire measures. Inj Prev. 2004 Apr;10(2):114-8.

7. Vincenten JA, Sector MJ, Rogmans W, Bouter L. Parents' perceptions, attitudes and behaviours towards child safety: a study in 14 European countries. Int J Inj Contr Saf Promot. 2005 Sep;12(3):183-9.

8. Woods AJ. The role of health professionals in childhood injury prevention: a systematic review of the literature. Patient Educ Couns. 2006 Dec;64(1-3):35-42.

9. Anglin D, Hutson HR, Kyriacou DN. Emergency medicine residents' perspectives on injury prevention. Ann Emerg Med. 1996 Jul;28(1):31-3.
10. Bazelmans C, Moreau M, Piette D, Bantuelle M, Levêque A. Role of physicians in preventing accidents in the home involving children under 15 years in the French-speaking community of Belgium. Inj Control Saf Promot. 2004 Dec;11(4):253-7.

11. Ehiri JE, Watt GC. The role of health visitors in the prevention of home accidents involving children: time for a rethink? Health Bull (Edinb). 1995 Jan;53(1):20-5.

12. Kendrick D, Marsh P, Williams EI. How do practice nurses see their role in childhood injury prevention? Inj Prev. 1995 Sep;1(3):159-63.

13. Cohen LR, Runyan CW. Barriers to pediatric injury prevention counseling. Inj Prev. 1999 Mar;5(1):36-40.

14. World Health Organization; UNICEF. World report on child injury prevention. Geneva: WHO; 2008.

15. Croatian National Institute of Public Health. Registry of Health Workers [Internet]. Croatian National Institute of Public Health [cited 2011 Jun 3]. Available from: http://www.hzjz.hr/djelatnici/index.html.

16. Gielen AC, Wilson ME, McDonald EM, Serwint JR, Andrews JS, Hwang WT, et al. Randomized trial of enhanced anticipatory guidance for injury prevention. Arch Pediatr Adolesc Med. 2001 Jan;155(1):42-9.

17. Evans SA, Kohli HS. Socioeconomic status and the prevention of child home injuries: a survey of parents of preschool children. Inj Prev. 1997 Mar;3(1):29-34.

18. Dowswell T, Towner EM, Simpson G, Jarvis SN. Preventing childhood unintentional injuries - what works? A literature review. Inj Prev. 1996 Jun;2(2):140-9.

Received February 12, 2014 Accepted in revised form August 18, 2014 